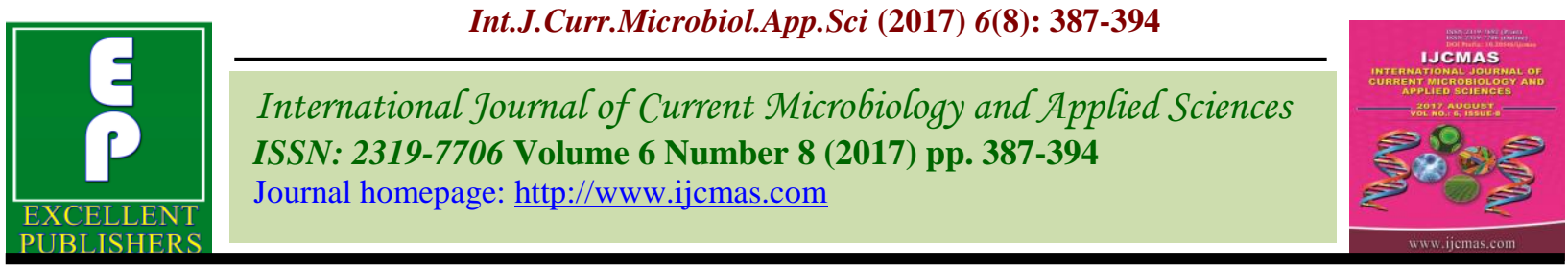

Original Research Article https://doi.org/10.20546/ijcmas.2017.608.052

\title{
Agronomic Performance of Rice (Oryza sativa L.) As Affected By planting System, Date of Transplanting, Source and Dose of Nitrogen
}

\author{
Rahul Yadav* and Thomas Abraham
}

\author{
Department of Agronomy, Sam Higginbottom University of Agriculture, Technology \& \\ Sciences, Allahabad, (U.P.) 211 007, India \\ *Corresponding author
}

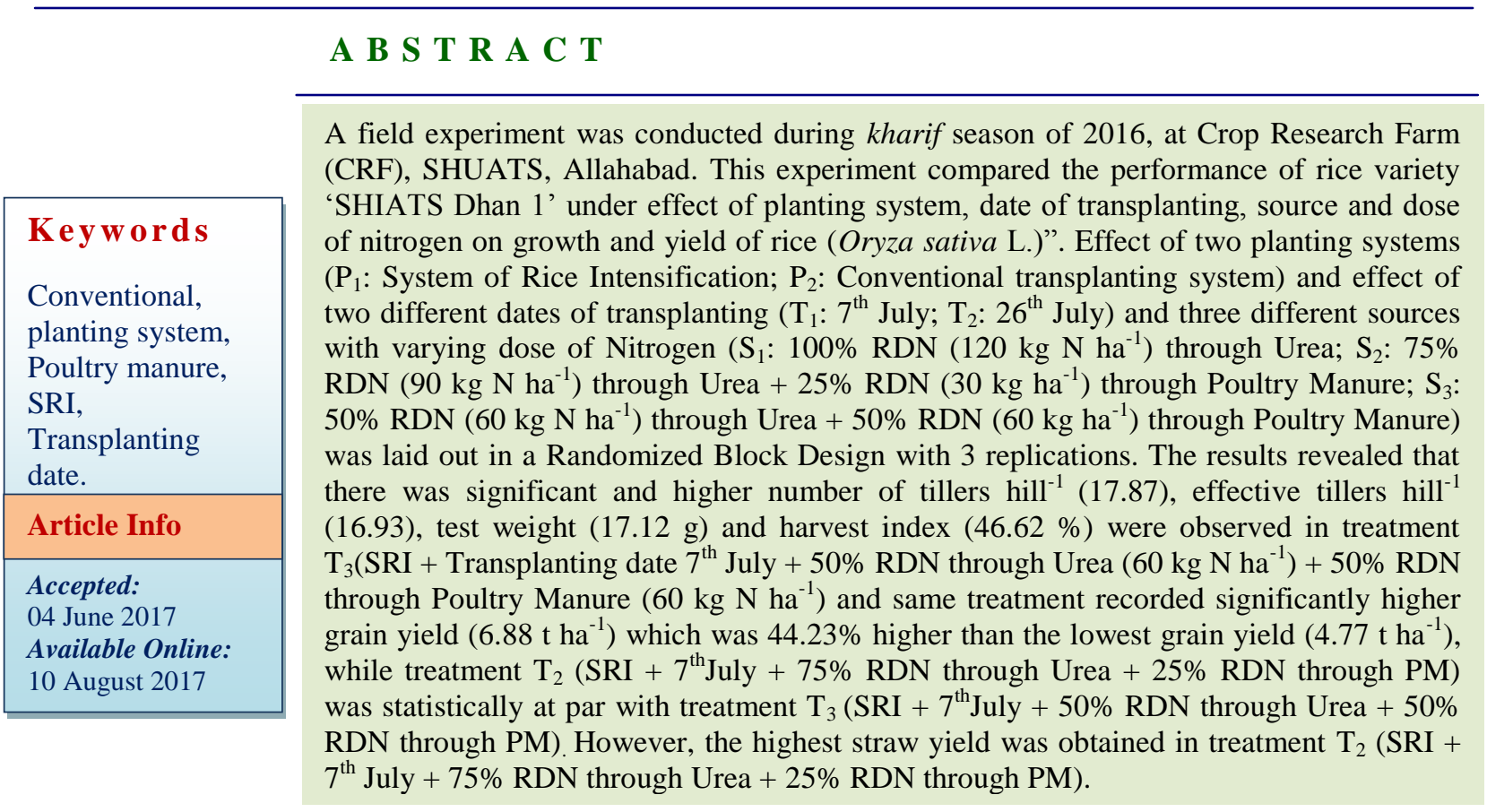

\section{Introduction}

Rice (Oryza sativa L.) is an important cereal crop which plays a key role in food security. More than $90 \%$ of total rice production in the world is consumed in Asian countries, where it is a staple food for a majority of the population (Mohanty, 2013). India has 44.14 million hectare area under rice and production of 106.65 million tonnes with an average yield of $2416 \mathrm{~kg} \mathrm{ha}^{-1}$ during 2013-14 (GOI, 2016). However, the need to produce more rice will increase if it has to meet the growing demand which is likely to be 130 million tonnes of milled rice in 2030. India needs to produce 1.7 million tonnes of additional rice every year to ensure national food security (Dass and Chandra, 2013). Uttar Pradesh has an area of $5.98 \mathrm{~m}$ ha, production of 14.64 million tonnes and productivity of $2.447 \mathrm{t} \mathrm{ha}^{-1}$ of rice (GOI, 2016).

Rice cultivation is a resource and cost intensive method since preparation of 
seedbed, raising of seedling and transplanting are labour and time intensive operations. Development and adoption of alternative rice production technologies to increase yield need to be emphasized in the context of land availability. Also, the rice seedlings lose much of their growth potential if they are transplanted more than 15 days after they emerge in the nursery (Manjunatha et al., 2010). The traditional method of rice cultivation has no ability to explore natural potential of the rice plant, because it's been transplanted with old seedlings, closely spaced and continual flooding which held back the plants natural potential.

The promising technologies generated by research can play a pivotal role in increasing productivity and thus food security of the nation. System of rice intensification can be a suitable methodology in this regard which decreases the use of inputs such as seeds and labour, is reported to have $20-30 \%$ higher or even more grain yield and lesser seed requirement as compared to conventional method of cultivation in India (DRR, 2007 and Mitra et al., 2013). Usually, timely transplanting and use of seedlings of appropriate age for transplanting are important non-cash inputs for realizing the higher productivity in rice (Pattar et al., 2001), and early transplanting of rice seedlings assumes special significance in obtaining higher yields in SRI cultivation.

Among the various cultural practices, date of transplanting, number of seedling and age of seedling are most important for yield maximization. Performance of a genotype entirely depends on the time of planting. Delay in planting generally results in yield reduction which cannot be compensated by any other means, transplanting of the photoperiod insensitive cultivars after 15 June can cause significant reduction in grain yield (Mahajan et al., 2009). Transplanting rice in the optimum period of time is critical to achieve high grain yield. However, optimum rice planting dates are regional and vary with location and genotypes (Bruns and Abbas, 2006; Sha and Linscombe, 2005). When crop is planted at the right time, tillering and growth proceeds normally.

Untamed and excessive use of toxic chemicals has shown ugly consequences expressing erratic pattern in the environment in general and the soil system in particular, which has drastically changed the soil biota (Abraham, 2009) and reduced the crop yield. Balanced and consumptive supply of plant nutrients supply holds the key for improving the food grain production and sustaining soil health. Consumptive use of organic manures and chemical fertilizers has advantages over use of only organic manures or chemical fertilizers (Kumar et al., 2009) by not only sustaining agricultural productivity and soil health, but also in substituting a part of fertilizer requirement by organics. The key to successful management is to match the nutritional requirements of the crop with nutrients available in the manure. Integration of organic and inorganic sources of nitrogen has been shown to considerably improve rice yields by minimizing nutrient losses to the environment and managing the nutrient supply, and thereby results in high nutrient use efficiency (Kumar et al., 2008, Bezbaruha et al., 2011, Parkinson, 2013).

\section{Materials and Methods}

A field experiment was conducted during summer season 2016, at the Crop Research Farm, Department of Agronomy, Naini Agricultural Institute, Sam Higginbottom University of Agriculture Technology and Sciences, Allahabad. The experiment site lies between $25-27^{\circ} \mathrm{N}$ latitude, $8.5^{\circ} \mathrm{E}$ Longitude and 98 meters altitude. The climate is characterized by the alternate hot rainy season 
from late June to early September with mean temperature of $38^{\circ} \mathrm{C}$. The soil was sandy loam in texture having a $\mathrm{pH}(7.6), \mathrm{EC}\left(0.26 \mathrm{dSm}^{-1}\right)$, organic carbon $(0.42 \%)$, available $\mathrm{N}(250 \mathrm{~kg}$ $\left.\mathrm{ha}^{-1}\right), \mathrm{P}\left(13.50 \mathrm{~kg} \mathrm{ha}^{-1}\right)$, and $\mathrm{K}\left(257.00 \mathrm{~kg} \mathrm{ha}^{-}\right.$ $\left.{ }^{1}\right)$ during the experimental year. The experiment was laid down in Randomized Block Design (RBD) with 12 treatment combinations of 2 planting system [System of Rice Intensification (SRI) and Conventional Transplanting System (CTS)], 2 dates of transplanting $\left(07^{\text {th }}\right.$ July and $26^{\text {th }}$ July) and 3 source and dose of nitrogen [100\% RDN (120 $\mathrm{kg} \mathrm{N} \mathrm{ha}^{-1}$ ) through Urea, 75\% RDN (90 kg N $\left.\mathrm{ha}^{-1}\right)$ through Urea $+25 \%$ RDN (30 kg ha $\left.{ }^{-1}\right)$ through Poultry Manure and 50\% RDN (60 $\mathrm{kg} \mathrm{N} \mathrm{ha}{ }^{-1}$ ) through Urea + 50\% RDN (60 kg $\mathrm{ha}^{-1}$ ) through Poultry Manure]. SHIATS Dhan 1 variety was used as planting material in this study.

Under SRI system, 12 days old seedlings were transplanted at a spacing of $25 \times 25 \mathrm{~cm}$, while under conventional transplanting 21 days old seedlings were transplanted at a spacing of $20 \times 15 \mathrm{~cm}$ in puddled soil. The

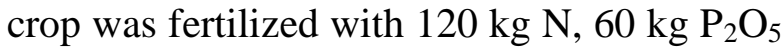
and $40 \mathrm{~kg} \mathrm{~K} \mathrm{~K}_{2} \mathrm{O}$. Phosphorous and Potassium were supplied through diammonium phosphate and muriate of potash, respectively, after taking into account the $\mathrm{P}$ and $\mathrm{K}$ supplied by the poultry manure.

Nitrogen was supplied through two sources viz., urea and poultry manure at different combination of doses. The half dose of $\mathrm{N}$ and entire dose of $\mathrm{P}$ and $\mathrm{K}$ were applied at the time of transplanting and rest of $\mathrm{N}$ was given in 2 equal splits, at tillering and panicle initiation stages. Irrigation was scheduled at 5-6 days interval during vegetative growth with $6 \mathrm{~cm}$ standing water maintained from tillering upto dough stage. For controlling of weeds in SRI, cono weeder was passed between lines at 22 and 40 days after transplanting (DAT). Data on number of effective tillers hill $^{-1}$ was recorded at crop maturity. Further, the data pertaining to test weight, grain yield and straw yield were recorded at the time of harvest of the crop. The economic parameters (net returns, B: C ratio) were worked on the basis of prevailing market prices of inputs and outputs. The data were analyzed by using the 'Analysis of Variance Technique' for Randomized Block Design (RBD). The treatment means were compared at $5 \%$ level of significance.

\section{Results and Discussion}

The data pertaining to different observations are being presented in tables 1 and 2 .

\section{Number of tillers hill-1}

Upon statistical analysis, it was observed that significant and highest number of tillers hill ${ }^{-1}$ (17.87) was recorded in treatment $\mathrm{T}_{3}(\mathrm{SRI}+$ $7^{\text {th }}$ July $+50 \%$ RDN through Urea $+50 \%$ RDN through PM) and lowest (8.00) in treatment $\mathrm{T}_{12}\left(\mathrm{CTR}+26^{\text {th }} \mathrm{July}+50 \% \mathrm{RDN}\right.$ through Urea $+50 \% \mathrm{RDN}$ through PM). Treatment $\mathrm{T}_{1}\left(\mathrm{SRI}+7^{\text {th }}\right.$ July $+100 \% \mathrm{RDN}$ through Urea) and $\mathrm{T}_{2}\left(\mathrm{SRI}+7^{\text {th }} \mathrm{July}+75 \%\right.$ RDN through Urea $+25 \%$ RDN through PM) were however, statistically at pat with treatment $\mathrm{T}_{3}\left(\mathrm{SRI}+7^{\text {th }}\right.$ July $+50 \% \mathrm{RDN}$ through Urea $+50 \%$ RDN through PM).

Early transplanted crop observed more duration and higher heat accumulation which might have favored most of the growth parameters, thereby improving the canopy's photosynthetic rate and tillering (Kumar et al., 1998). Planting in square geometry with wider spacing might have resulted in profuse tillering under SRI cultivation, which might have facilitated plants for better utilization of the resources (nutrients, air, light and moisture) (Krishna and Biradarpatil, 2009). Moreover, the higher root growth and nutrient uptake promoted by weeder use may have resulted in increased tillering rate under SRI (Prabha et al., 2011). 


\section{Dry weight (g hill $\left.{ }^{-1}\right)$}

Significant and highest dry weight $(60.79 \mathrm{~g}$ hill $\left.^{-1}\right)$ was observed in treatment $\mathrm{T}_{3}\left(\mathrm{SRI}+7^{\mathrm{th}}\right.$ July $+50 \%$ RDN through Urea $+50 \%$ RDN through PM), while lowest dry weight (32.13 $\mathrm{g}$ hill $\left.^{-1}\right)$ was observed in treatment $\mathrm{T}_{12}(\mathrm{CTR}+$ $26^{\text {th }}$ July $+50 \%$ RDN through Urea $+50 \%$ RDN through PM). However, statistical parity was observed in treatments $\mathrm{T}_{1}\left(\mathrm{SRI}+7^{\text {th }} \mathrm{July}\right.$ $+100 \%$ RDN through Urea), $\mathrm{T}_{2}$ (SRI $+7^{\text {th }}$ July $+75 \%$ RDN through Urea $+25 \%$ RDN through PM), $\mathrm{T}_{5}\left(\mathrm{SRI}+26^{\text {th }} \mathrm{July}+75 \% \mathrm{RDN}\right.$ through Urea $+25 \%$ RDN through PM) and $\mathrm{T}_{6}\left(\mathrm{SRI}+26^{\text {th }}\right.$ July $+50 \%$ RDN through Urea $+50 \%$ RDN through PM).

The integrated use of appropriate proportion of organic manures and chemical fertilizers may have accrued the $\mathrm{N}$ accumulation in the foliage thereby improving growth and controlled senescence of the whole plant and ultimately causing more dry matter production to meet the appropriate need of sink capacity of the medium duration rice (Mondal et al.,2015). The transplanting of younger aged seedlings along with soil, keeping the roots intact may have resulted in early adaptation of the seedling to soil and climatic condition thereby recording a higher dry weight in such plants. This corroborates with Uphoff (2002).

\section{Number of effective tillers hill ${ }^{-1}$}

Significant and highest number of effective tillers hill $^{-1}$ (16.93) were observed in treatment $\mathrm{T}_{3}\left(\mathrm{SRI}+7^{\text {th }}\right.$ July $+50 \% \mathrm{RDN}$ through Urea $+50 \%$ RDN through PM). However, $\mathrm{T}_{1}\left(\mathrm{SRI}+7^{\text {th }}\right.$ July $+100 \%$ RDN through Urea) and $\mathrm{T}_{2}$ (SRI $+7^{\text {th }}$ July $+75 \%$ RDN through Urea $+25 \%$ RDN through PM) were found to be statistically at par with treatment $\mathrm{T}_{3}\left(\mathrm{SRI}+7^{\text {th }}\right.$ July $+50 \% \mathrm{RDN}$ through Urea $+50 \%$ RDN through PM). This might be owing to longer growing period of the crop for better development of parts to allocate greater accumulation of photosynthates in early planting, resulting in the better development of growth and yield attributes (Singh et al., 2004).

\section{Test weight $(\mathrm{g})$}

Highest test weight (17.12 g) was recorded in treatment $\mathrm{T}_{3}\left(\mathrm{SRI}+7^{\text {th }}\right.$ July $+50 \% \mathrm{RDN}$ through Urea $+50 \%$ RDN through PM). However, treatments $\mathrm{T}_{1}$ (SRI $+7^{\text {th }}$ July + $100 \%$ RDN through Urea), $\mathrm{T}_{2}$ (SRI $+7^{\text {th }}$ July $+75 \%$ RDN through Urea $+25 \%$ RDN through $\mathrm{PM}), \mathrm{T}_{4}\left(\mathrm{SRI}+26^{\text {th }} \mathrm{July}+100 \%\right.$ RDN through Urea), $\mathrm{T}_{5}\left(\mathrm{SRI}+26^{\text {th }}\right.$ July + $75 \%$ RDN through Urea $+25 \%$ RDN through $\mathrm{PM})$ and $\mathrm{T}_{6}\left(\mathrm{SRI}+26^{\text {th }}\right.$ July $+50 \% \mathrm{RDN}$ through Urea $+50 \%$ RDN through PM) were found to be statistically at par with treatment $\mathrm{T}_{3}$ (SRI $+7^{\text {th }}$ July $+50 \%$ RDN through Urea $+50 \%$ RDN through PM). Profuse root growth and tillering increases assimilates synthesis and divert to support greater grain filling leading to higher test weight in SRI (Shukla et al., 2014). This finding is parallel with that of Singh et al., (2013); Jain and Upadhyay (2008), who also reported similar results.

\section{Grain yield (t ha $\left.{ }^{-1}\right)$}

A perusal of table 2 clearly shows that treatment $\mathrm{T}_{3}\left(\mathrm{SRI}+7^{\text {th }}\right.$ July $+50 \%$ RDN through Urea $+50 \%$ RDN through PM) recorded the highest grain yield $\left(6.88 \mathrm{t} \mathrm{ha}^{-1}\right)$. However, treatment $\mathrm{T}_{2}$ (SRI $+7^{\text {th }}$ July $+75 \%$ RDN through Urea $+25 \%$ RDN through PM) is statistically at par with treatment $\mathrm{T}_{3}$ (SRI + $7^{\text {th }}$ July $+50 \%$ RDN through Urea $+50 \%$ RDN through PM). When sown late, the important growth phases of rice crop especially the grain filling stage might coincide with lower temperature, resulting in high sterility percentage, thereby reduction in yield (Hussain et al., 2009). This is in conformity with Vishwakarma et al., (2016). 
Table.1 Effect of planting system, date of transplanting, source and dose of nitrogen on number of tillers hill ${ }^{-1}$, dry weight, Number of effective tillers hill ${ }^{-1}$ and test weight of rice

\begin{tabular}{|c|c|c|c|c|c|}
\hline & Treatment & No. of tillers hill ${ }^{-1}$ & Dry weight $(g)$ & $\begin{array}{l}\text { No. of effective tillers } \\
\text { hill }^{-1}\end{array}$ & $\begin{array}{l}\text { Test weight } \\
\text { (g) }\end{array}$ \\
\hline $\mathrm{T}_{1}$ & SRI $+7^{\text {th }}$ July $+100 \%$ RDN through Urea & 16.60 & 60.70 & 15.73 & 16.76 \\
\hline $\mathrm{T}_{2}$ & SRI $+7^{\text {th }}$ July $+75 \%$ RDN through Urea $+25 \%$ RDN through PM & 16.93 & 60.46 & 16.13 & 16.99 \\
\hline $\mathrm{T}_{3}$ & SRI $+7^{\text {th }}$ July $+50 \%$ RDN through Urea $+50 \%$ RDN through PM & 17.87 & 60.79 & 16.93 & 17.12 \\
\hline $\mathrm{T}_{4}$ & SRI $+26^{\text {th }}$ July $+100 \%$ RDN through Urea & 15.27 & 59.01 & 14.53 & 16.59 \\
\hline $\mathrm{T}_{5}$ & SRI $+26^{\text {th }}$ July $+75 \%$ RDN through Urea $+25 \%$ RDN through PM & 15.53 & 59.52 & 14.67 & 16.70 \\
\hline $\mathrm{T}_{6}$ & $\mathrm{SRI}+26^{\text {th }}$ July $+50 \%$ RDN through Urea $+50 \%$ RDN through PM & 15.73 & 60.73 & 15.13 & 16.86 \\
\hline $\mathrm{T}_{7}$ & CTR $+7^{\text {th }}$ July $+100 \%$ RDN through Urea & 10.87 & 33.98 & 9.73 & 15.69 \\
\hline $\mathrm{T}_{8}$ & $\mathrm{CTR}+7^{\text {th }}$ July $+75 \%$ RDN through Urea $+25 \%$ RDN through PM & 11.07 & 34.41 & 9.87 & 15.72 \\
\hline $\mathrm{T}_{9}$ & $\mathrm{CTR}+7^{\text {th }}$ July $+50 \%$ RDN through Urea $+50 \%$ RDN through PM & 10.77 & 33.22 & 9.60 & 15.44 \\
\hline $\mathrm{T}_{10}$ & $\mathrm{CTR}+26^{\text {th }}$ July $+100 \%$ RDN through Urea & 8.47 & 32.96 & 7.60 & 15.43 \\
\hline $\mathrm{T}_{11}$ & $\mathrm{CTR}+26^{\text {th }}$ July $+75 \%$ RDN through Urea $+25 \%$ RDN through PM & 8.63 & 33.49 & 7.67 & 15.83 \\
\hline \multirow[t]{5}{*}{$\mathrm{T}_{12}$} & $\mathrm{CTR}+26^{\text {th }}$ July $+50 \%$ RDN through Urea $+50 \%$ RDN through PM & 8.00 & 32.13 & 7.27 & 15.41 \\
\hline & F test & $\mathrm{S}$ & $\mathrm{S}$ & $\mathrm{S}$ & S \\
\hline & SEd $( \pm)$ & 0.91 & 0.69 & 0.58 & 0.28 \\
\hline & $\mathrm{CD}(\mathrm{P}=0.05)$ & 1.89 & 1.43 & 1.21 & 0.58 \\
\hline & $\mathrm{CV}(\%)$ & 8.59 & 1.81 & 5.92 & 2.12 \\
\hline
\end{tabular}

Table.2 Effect of planting system, date of transplanting, source and dose of nitrogen on grain yield, straw yield, net return and

\begin{tabular}{|c|c|c|c|c|c|}
\hline & Treatment & $\begin{array}{c}\text { Grain yield } \\
\left(\mathrm{t} \mathrm{ha}^{-1}\right)\end{array}$ & $\begin{array}{c}\text { Straw yield } \\
\left(\mathrm{t} \mathrm{ha}^{-1}\right)\end{array}$ & $\begin{array}{l}\text { Net return } \\
\left(₹ \text { ha }^{-1}\right)\end{array}$ & $\begin{array}{l}\text { B: C } \\
\text { ratio }\end{array}$ \\
\hline $\mathrm{T}_{1}$ & SRI $+7^{\text {th }}$ July $+100 \%$ RDN through Urea & 6.30 & 7.49 & 48432.64 & 1.79 \\
\hline $\mathrm{T}_{2}$ & SRI $+7^{\text {th }}$ July $+75 \%$ RDN through Urea $+25 \%$ RDN through PM & 6.63 & 8.04 & 51307.54 & 1.79 \\
\hline $\mathrm{T}_{3}$ & SRI $+7^{\text {th }}$ July $+50 \%$ RDN through Urea $+50 \%$ RDN through PM & 6.88 & 7.89 & 50902.06 & 1.74 \\
\hline $\mathrm{T}_{4}$ & $\mathrm{SRI}+26^{\text {th }}$ July $+100 \%$ RDN through Urea & 5.76 & 7.16 & 39686.74 & 1.64 \\
\hline $\mathrm{T}_{5}$ & $\mathrm{SRI}+26^{\text {th }} \mathrm{July}+75 \%$ RDN through Urea $+25 \%$ RDN through PM & 5.93 & 7.50 & 39760.44 & 1.61 \\
\hline $\mathrm{T}_{6}$ & $\mathrm{SRI}+26^{\text {th }}$ July $+50 \%$ RDN through Urea $+50 \%$ RDN through PM & 6.38 & 7.76 & 43112.06 & 1.63 \\
\hline $\mathrm{T}_{7}$ & $\mathrm{CTR}+7^{\text {th }}$ July $+100 \%$ RDN through Urea & 5.19 & 6.84 & 27290.24 & 1.42 \\
\hline $\mathrm{T}_{8}$ & $\mathrm{CTR}+7^{\text {th }}$ July $+75 \%$ RDN through Urea $+25 \%$ RDN through PM & 5.46 & 7.05 & 28676.54 & 1.42 \\
\hline $\mathrm{T}_{9}$ & $\mathrm{CTR}+7^{\text {th }}$ July $+50 \%$ RDN through Urea $+50 \%$ RDN through PM & 4.98 & 6.74 & 16847.26 & 1.23 \\
\hline $\mathrm{T}_{10}$ & $\mathrm{CTR}+26^{\text {th }}$ July $+100 \%$ RDN through Urea & 4.77 & 6.56 & 20503.84 & 1.31 \\
\hline $\mathrm{T}_{11}$ & $\mathrm{CTR}+26^{\text {th }}$ July $+75 \%$ RDN through Urea $+25 \%$ RDN through PM & 5.13 & 6.68 & 22948.94 & 1.34 \\
\hline \multirow[t]{5}{*}{$\mathrm{T}_{12}$} & $\mathrm{CTR}+26^{\text {th }}$ July $+50 \%$ RDN through Urea $+50 \%$ RDN through PM & 4.93 & 6.78 & 16148.66 & 1.22 \\
\hline & F test & $\mathrm{S}$ & $\mathrm{S}$ & $\mathrm{S}$ & $\mathrm{S}$ \\
\hline & SEd $( \pm)$ & 0.16 & 0.26 & 2902.46 & 0.04 \\
\hline & $\mathrm{CD}(\mathrm{P}=0.05)$ & 0.34 & 0.53 & 6019.33 & 0.09 \\
\hline & $\mathrm{CV}(\%)$ & 3.52 & 4.37 & 10.52 & 3.57 \\
\hline
\end{tabular}

SRI: System of Rice Intensification, CTR: Conventional transplanted rice, PM: Poultry manure, RDN: Recommended dose of nitrogen (120 kg ha $\left.{ }^{-1}\right)$ 
Alim (2012) reported that the grain yield progressively increased with the increase of organic manure which might be due to the presence of organic manure that enhanced the effectiveness of chemical fertilizer. All the factors when combined together may have attributed to the significant and highest grain yield in treatment $\mathrm{T}_{3}\left(\mathrm{SRI}+7^{\text {th }}\right.$ July $+50 \%$ RDN through Urea $+50 \%$ RDN through PM).

\section{Straw yield ( $\left.\mathrm{t} \mathrm{ha}^{-1}\right)$}

The highest straw yield $\left(8.04 \mathrm{t} \mathrm{ha}^{-1}\right)$ was recorded in treatment $\mathrm{T}_{2}\left(\mathrm{SRI}+7^{\text {th }} \mathrm{July}+75 \%\right.$ RDN through Urea $+25 \%$ RDN through PM), while treatment $\mathrm{T}_{3}\left(\mathrm{SRI}+7^{\text {th }} \mathrm{July}+50 \% \mathrm{RDN}\right.$ through Urea $+50 \%$ RDN through PM) and $\mathrm{T}_{6}\left(\mathrm{SRI}+26^{\text {th }}\right.$ July $+50 \%$ RDN through Urea $+50 \%$ RDN through PM) were found to be statistically at par with treatment $\mathrm{T}_{2}\left(\mathrm{SRI}+7^{\text {th }}\right.$ July $+75 \%$ RDN through Urea $+25 \%$ RDN through PM).

This may be attributed to the fact that transplanting seedlings at a younger stage might provide sufficient nutrients for vegetative growth and also for the reproductive phase, which might ultimately lead to increased plant height and dry matter production, thereby resulting in increased straw yields (Krishna, 2000).

\section{Harvest index (\%)}

Highest harvest index (46.62\%) was recorded in treatment $\mathrm{T}_{3}\left(\mathrm{SRI}+7^{\text {th }} \mathrm{July}+50 \% \mathrm{RDN}\right.$ through Urea $+50 \%$ RDN through PM), with treatment $\mathrm{T}_{1}\left(\mathrm{SRI}+7^{\text {th }}\right.$ July $+100 \%$ RDN through Urea) showing statistical parity with that of $\mathrm{T}_{3}\left(\mathrm{SRI}+7^{\text {th }} \mathrm{July}+50 \% \mathrm{RDN}\right.$ through Urea $+50 \%$ RDN through PM). Mohanty et al., (2014) observed that the crop establishment methods differed for the harvest index parameter with SRI recording the highest harvest index, followed by conventional transplanting and direct sowing, which might be due to better translocation of photosynthates from source to sink in case of SRI.

\section{Economics}

The highest net return (51307.54 ₹ ha $\left.{ }^{-1}\right)$ was recorded in treatment $\mathrm{T}_{2}\left(\mathrm{SRI}+7^{\text {th }} \mathrm{July}+\right.$ $75 \%$ RDN through Urea $+25 \%$ RDN through PM), while highest benefit cost ratio (1.79) was observed in treatment $\mathrm{T}_{1}\left(\mathrm{SRI}+7^{\text {th }} \mathrm{July}+\right.$ $100 \%$ RDN through Urea) as well as treatment $\mathrm{T}_{2}$ (SRI $+7^{\text {th }}$ July $+75 \%$ RDN through Urea $+25 \%$ RDN through PM). Transplanting of younger seedling fetched significantly higher economic returns and B: $C$ ratio over older age seedling (Shukla et al., 2014), which was due to the higher grain and straw yield in treatments with younger seedling (Singh et al., 2013). Moreover, saving on seed cost was evident from the fact that only $5 \mathrm{~kg}$ seed hectare ${ }^{-1}$ for SRI as against $30-40 \quad \mathrm{~kg}$ for conventional transplanting (Kumar et al., 2009).

From the data pertaining to the different treatments, it may be indicated that by suitably modifying the SRI practices such as use of both organic and inorganic sources for supplying nutrients, higher grain yield and monetary benefits can be realized over traditional transplanting. Similarly, transplanting on $7^{\text {th }}$ July was found to be more effective for grain yield, number of tillers and dry-matter accumulation as compared to transplanting on $26^{\text {th }}$ July, thus indicating that early/timely transplanting is more beneficial.

\section{References}

Abraham, T. 2009. Organic farming: the ultimate strategy to combat antimicrobial resistance. (In:) Proceedings of National Conference on Antimicrobial Resistance: From Emerging Threat To Reality; Rubina Lawrence (Ed.). Narosa Publishing 
House Pvt. Ltd., New Delhi, (1st ed., 2009). pp. 174-181.

Alim, M.A. 2012. Effect of Organic and Inorganic Sources and Doses of Nitrogen Fertilizer on the Yield of Boro Rice. J. Environ. Sci. Natural Resources 5 (1): 273- 282.

Bezbaruha, R., Sharma, R.C., and Banik, P. 2011. Effect of Nutrient Management and Planting Geometry on Productivity of Hybrid Rice (Oryza sativa L.) Cultivars. American Journal of Plant Sciences, 2(3): 297-302.

Bruns, H.A. and Abbas, H.K. 2006. Planting date effects on Bt and Non-Bt corn in the mid-south USA. Agron. J., 98: 100106.

Dass, A. and Chandra, S. 2013. Irrigation, spacing and cultivar effects on net photosynthetic rate, dry matter partitioning and productivity of rice under system of rice intensification in Mollisol of northern India. Experimental Agriculture., 49 (4): 504 23.

DRR. 2007. Evaluation of different crop establishment methods for increasing crop yield in transplanting rice. Directorate of Rice Research Annual Progress Report 3, 4.99-4.101.

GOI. 2016. Agricultural statistics at a glance: Ministry of Agriculture and Farmers Welfare, Government of India. Retrieved from: http://eands.dacnet.nic. in/PDF/Agricultural_Statistics_At_Glan ce-2015.pdf

Hussain, A., Bhat, M.A., Ganai, M.A. and Hussain, T. 2009. Influence of planting dates and spacing schedules on performance of Basmati rice Pusa Sugandh-3 under Kashmir valley conditions. Environ. Ecol., 27: 396-398.

Jain, A. and Upadhyay, V.B. 2008. Effect of planting geometry and age of seedlings on the performance of inbred and hybrid rice under system of rice intensification
(SRI). Haryana Journal of Agronomy, 24(1\&2): 16-8.

Krishna, A. 2000.Effect of age of seedlings on performance of rice (Oryza sativa L.) cultivars under late planted condition. J. Res. ANGRAU, 28: 73-74.

Krishna, A. and Biradarpatil, N.K. 2009. Influence of seedling age and spacing on seed yield and quality of short duration rice under system of rice intensification cultivation. Karnataka J. Agric. Sci., 22(1): 53-55.

Kumar, M.R., Subbiah, S.V. and Pillai, G.K. 1998. Response of rice hybrids to different dates of planting in vertisols of Andhra Pradesh. Oryza, 35(3): 285-287.

Kumar, J. and Yadav, M.P. 2008. Effect of Integrated Nutrient Management on Growth, Yield Attributes, Yield and Economics of Hybrid Rice (Oryza sativa L.). Research on Crops, 9:10-3.

Kumar, R.M., Surekha, K., Padmavathi, C., Subbarao, L.V., Latha, P.C., Prasad, M.S., Ravindrababu, V., Ramprasad, A.S., Rupela, O.P., Goud, V., Muthuraman, P., Somashekhar, N., Ravichandran, S.M., Singh, S.P., Viraktamath, B.C., 2009. Research experiences on system of rice intensification and future directions. Journal of Rice Research, 2(2): 61-71.

Mahajan, G., Bharaj, T.S. and Timsina, J. 2009. Yield and water productivity of rice as affected by time of transplanting in Punjab, India. Agricultural Water Management, 96: 525-532.

Manjunatha, B.N., Basavarajappa, R. and Pujari, B.T. 2010. Effect of age of seedlings on growth, yield and water requirement by different system of rice intensification. Karnataka Journal of Agricultural Sciences 23(2): 231-234.

Mitra, B., Mookherjee, S., Biswas, S., Mukhopadhyay, P. 2013. Potential Water Saving through System of Rice Intensification (SRI) in Terai Region of 
West Bengal, India. International Journal of Bio-resource and Stress Management, 4(3), 449-451.

Mohanty, S. 2013. Trends in global rice consumptions. Rice Today, 12 (1), 4445.

Mohanty, T.R., Maity S.K., Roul, P.K. and Sahoo, K.C. 2014.Studies on Yield, Economics and Energetics of Rice (Oryza sativa L.) in Relation to Crop Establishment Methods and Nutrient Management Practices. International Journal of Bio-resource and Stress Management, 5(4): 495-501.

Mondal, S., Mallikarjun, M., Ghosh, M., Ghosh, D.C. and Timsina, J. 2015.Effect of Integrated Nutrient Management on Growth and Productivity of Hybrid Rice. Journal of Agricultural Science and Technology, 5: 297-308.

Parkinson, R. 2013. System Based Integrated Nutrient Management. Soil Use Management, 29(4): 608.

Pattar, P.S., Reddy, B.G.M. and Kuchanur, P.H. 2001.Yield and yield parameters of rice (Oryza sativa L.) as influenced by date of planting and age of seedlings. Indian Journal of Agricultural Sciences, 71(8): 521-522.

Prabha, A.C.S., Thiyagarajan, T.M. and Senthivelu, M. 2011. System of Rice Intensification Principles on Growth Parameters, Yield Attributes and Yields of Rice (Oryza sativa L.). Journal of Agronomy, 10(1): 27-33.

Sha, X., Linscombe, S.D. 2005. Planting date is critical for maximizing rice yield and milling quality. Louisiana Agric., 48(3): 6-8.

Shukla, U.N., Srivastava, V.K., Singh, S., Sen, A. and Kumar, V. 2014. Growth, yield and economic potential of rice (Oryza sativa) as influenced by different age of seedlings, cultivars and weed management under system of rice intensification. Indian Journal of Agricultural Sciences, 84(5): 628-36.

Singh, T., Shivay, Y.S. and Singh, S. 2004. Effect of date and transplanting and nitrogen on productivity and nitrogen use induces in hybrid and non-hybrid aromatic rice. Acta Agronomica Hungarica, 52(3): 245-252.

Singh, K., Singh, S.R., Singh, J.K., Rathore, R.S., Pal, S., Singh, S.P. and Roy, R. 2013. Effect of age of seedling and spacing on yield, economics, soil health and digestibility of rice (Oryza sativa) genotypes under system of rice intensification. Indian Journal of Agricultural Sciences, 83(5): 479-83.

Vishwakarma, A., Singh, J.K., Sen, A., Bohra, J.S and Singh, S. 2016. Effect of transplanting date and age of seedlings on growth, yield and quality of hybrids under system of rice (Oryza sativa) intensification and their effect on soil fertility. Indian Journal of Agricultural Sciences, 86(5): 679-85.

Uphoff, N. 2002.System of Rice Intensification (SRI) for enhancing the productivity of land, labour and water. Journal of Agricultural Resource Management, 1: 43-49.

\section{How to cite this article:}

Rahul Yadav and Thomas Abraham. 2017. Agronomic Performance of Rice (Oryza sativa L.) As Affected By planting System, Date of Transplanting, Source and Dose of Nitrogen. Int.J.Curr.Microbiol.App.Sci. 6(8): 387-394. doi: https://doi.org/10.20546/ijcmas.2017.608.052 